\title{
UVA-LED Technology's Treatment Efficiency and Cost in a Competitive Trial Applied to the Photo-Fenton Treatment of Landfill Leachate
}

\author{
Javier Tejera $^{1}$, Antonio Gascó ${ }^{2}$ (D), Daphne Hermosilla ${ }^{2,3}$, Víctor Alonso-Gomez ${ }^{4}$ (D) Carlos $^{\text {Negro }}{ }^{1}(\mathbb{D}$ \\ and Ángeles Blanco 1,*iD
}

1 Department of Chemical Engineering and Materials, Facultad de Ciencias Químicas, Universidad Complutense de Madrid, Avenida Complutense, 28040 Madrid, Spain; jttejo@ucm.es (J.T.); cnegro@ucm.es (C.N.)

2 Department of Forest and Environmental Engineering and Management, E.T.S.I. Montes, Forestal y del Medio Natural, Universidad Politécnica de Madrid, 28040 Madrid, Spain; antonio.gasco@upm.es (A.G.); daphne.hermosilla@upm.es (D.H.)

3 Department of Agricultural and Forest Engineering, Campus Duques de Soria, University of Valladolid, EIFAB, 42005 Soria, Spain

4 Department of Applied Physics, Campus Duques de Soria, University of Valladolid, EIFAB, 42005 Soria, Spain; victor.alonso.gomez@uva.es

* Correspondence: ablanco@ucm.es

\section{check for} updates

Citation: Tejera, J.; Gascó, A.; Hermosilla, D.; Alonso-Gomez, V.; Negro, C.; Blanco, Á. UVA-LED Technology's Treatment Efficiency and Cost in a Competitive Trial Applied to the Photo-Fenton Treatment of Landfill Leachate. Processes 2021, 9, 1026. https:// doi.org/10.3390/pr9061026

Academic Editors: Xiangchao Meng and Jason Zhang

Received: 10 May 2021

Accepted: 4 June 2021

Published: 10 June 2021

Publisher's Note: MDPI stays neutral with regard to jurisdictional claims in published maps and institutional affiliations.

Copyright: (c) 2021 by the authors. Licensee MDPI, Basel, Switzerland. This article is an open access article distributed under the terms and conditions of the Creative Commons Attribution (CC BY) license (https:/ / creativecommons.org/licenses/by/ $4.0 /)$.
Abstract: The objective of this trial was to assess the application of UVA-LED technology as an alternative source of irradiation for photo-Fenton processes, aiming to reduce treatment costs and provide a feasible treatment for landfill leachate. An optimized combination of coagulation with ferric chloride followed by photo-Fenton treatment of landfill leachate was optimized. Three different radiation sources were tested, namely, two conventional high-pressure mercury-vapor immersion lamps (100 W and $450 \mathrm{~W}$ ) and a custom-designed $8 \mathrm{~W} 365 \mathrm{~nm}$ UVA-LED lamp. The proposed treatment combination resulted in very efficient degradation of landfill leachate (COD removal $=90 \%$ ). The coagulation pre-treatment removed about $70 \%$ of the COD and provided the necessary amount of iron for the subsequent photo-Fenton treatment, and it further favored this process by acidifying the solution to an optimum initial $\mathrm{pH}$ of 2.8 . The $90 \%$ removal of color improved the penetration of radiation into the medium and by extension improved treatment efficiency. The faster the Fenton reactions were, as determined by the stoichiometric optimum set-up reaction condition of $\left[\mathrm{H}_{2} \mathrm{O}_{2}\right]_{0} / \mathrm{COD}_{0}=2.125$, the better were the treatment results in terms of COD removal and biodegradability enhancement because the chances to scavenge oxidant agents were limited. The $100 \mathrm{~W}$ lamp was the least efficient one in terms of final effluent quality and operational cost figures. UVA-LED technology, assessed as the application of an $8 \mathrm{~W} 365 \mathrm{~nm}$ lamp, provided competitive results in terms of COD removal, biodegradability enhancement, and operational costs (35-55\%) when compared to the performance of the $450 \mathrm{~W}$ conventional lamp.

Keywords: coagulation pre-treatment; landfill leachate; photo-Fenton; UVA-LED; wastewater treatment cost; combined treatment

\section{Introduction}

The human population's activities and the industrialization process have generated an important increase of municipal solid waste over the last decades. According to waste management hierarchy, landfilling is addressed as the least favorable strategy and should be the last option for waste management [1,2]. Rainfall percolation through disposed waste generates landfill leachate (LL); the characteristics of LL are widely different, mainly depending on its age, the origin of waste, and climate conditions [3-5].

The preferred technologies for LL treatment are biological processes because of their lower cost, but they require highly biodegradable LL (typically expressed as $\mathrm{BOD}_{5} / \mathrm{COD}$ ). 
Depending on age, LL may be classified as young or mature. Young LL is characterized by a high $\mathrm{BOD}_{5} / \mathrm{COD}$ ratio; thus, it can successfully be treated by biological processes [6]. As time passes, LL turns into mature LL, undergoing self-degradation processes that lead to low $\mathrm{BOD}_{5} / \mathrm{COD}$ ratios. Consequently, mature LL cannot efficiently be treated by biological processes; thus, alternative technologies must be considered for its successful depuration. Advanced oxidation processes (AOPs) are the most popular methods that have been addressed to degrade bio-recalcitrant matter because they are able to enhance the biodegradability of LL [7-14]. One of the most common AOPs used for this purpose is the Fenton reaction [15-17], which consists in the generation of hydroxyl radicals, which hold great oxidative power, to degrade organic matter through the reaction between hydrogen peroxide and $\mathrm{Fe}^{2+}$, as it is shown in Equation (1):

$$
\mathrm{H}_{2} \mathrm{O}_{2}+\mathrm{Fe}^{2+} \rightarrow \cdot \mathrm{OH}+\mathrm{Fe}^{3+}
$$

An improvement of this conventional Fenton reaction consists in using UV radiation to reduce $\mathrm{Fe}^{3+}$ to $\mathrm{Fe}^{2+}$, that is, the so-called photo-Fenton process [18-21], which enables the iron oxidation cycle to be produced again, generating more hydroxyl radicals capable of further oxidizing the remaining organic matter. As a result, it is necessary to add less iron to catalyze the process, and the production of iron sludge is minimized [22].

Different sources of UV radiation have already been assessed in their application to perform the photo-Fenton reaction, namely, high-pressure mercury-vapor immersion lamps $[7,21]$, sunlight concentrated in compound parabolic collectors (CPC) [23,24], unconcentrated sunlight in thin film reactors [25], and light-emitting diodes (LEDs) [26]. In particular, Singa et al. (2018) [21] addressed a 68\% COD removal in 90 min of treatment using a $16 \mathrm{~W}$ high-pressure mercury-vapor immersion lamp to perform the photo-Fenton degradation of LL. Colombo et al. (2019) [7] achieved an 89\% COD removal in a similar photo-Fenton treatment of a sanitary LL, and the reported treatment efficiency increased up to the $98 \%$ removal of the COD when the oxidation process was combined with a posterior biological treatment. Furthermore, Gomes et al. (2018) [23] reported an 80\% COD removal when a sunlight CPC was used to assist the Fenton reaction of urban mature leachate. Silva et al. (2015) [20] assessed the scale-up of the photo-Fenton treatment to oxidize $100 \mathrm{~m}^{3}$ day $^{-1}$ of bio-treated LL with an initial COD of $2945-4864 \mathrm{mg} \mathrm{O}_{2} \mathrm{~L}^{-1}$, and reported a $65-80 \%$ COD removal assisting the process with CPCs, UV immersion mercury lamps, or the combination of both. Zhao et al. (2020) [27] reported 93\% COD removal when treating a nanofiltered LL of $1280 \mathrm{mg} \mathrm{O}_{2} \mathrm{~L}^{-1}$, in a continuous photo-Fenton treatment.

Particularly, Simaoui et al. (2019) [26] achieved a limited 48\% COD removal applying an LED photo-Fenton treatment, which increased to $62 \%$ when the leachate was pre-coagulated. In a previous study, Tejera et al. (2019) achieved 90\% COD removal when combining coagulation/flocculation with ferric chloride followed by a photo-Fenton treatment with a UV immersion mercury lamp [28]; hence, further research on LED technology use is required to develop an efficient viable alternative UV photo-Fenton treatment.

Other authors have reported the use of different complexes with iron to catalyze the photo-Fenton process. For example, Borba et al. (2019) [29] reported the application of oxalic acid to enhance the photo-Fenton treatment of LL, achieving an $86 \%$ COD removal at pH 7.8 by adding an $\mathrm{Fe}^{3+}$ dose of $90 \mathrm{mg} \mathrm{L}^{-1}$. Seibert et al. (2017) [30] achieved a $62 \%$ COD removal when using EDTA as a chelating agent for iron support in the treatment of LL by the photo-Fenton process.

In addition, some authors have also reported rough cost assessments of photoFenton combined treatment alternatives using different irradiation sources. In particular, Cassano et al. (2011) [18] compared the estimated cost of several alternatives of treatment for a moderately biodegradable medium-age $\mathrm{LL}\left(\mathrm{BOD}_{5} / \mathrm{COD}=0.2-0.3\right)$ in order to reduce its initial COD of 2.8-3.6 $\mathrm{g} \mathrm{O}_{2} \mathrm{~L}^{-1}$ down to $<0.5$ or $<1.6 \mathrm{~g} \mathrm{~L}^{-1}$ depending on whether it was going to be discharged to the sewer or the receiving water bodies, respectively. In the strictest case, a cost of $4.8 \mathrm{EUR} \mathrm{m}^{-3}$ was estimated for a sequencing batch biofilter granular reactor followed by ozonation and a solar photo-Fenton treatment. In addition, 
Silva et al. (2016) [24] considered different irradiation sources for their assessment of the photo-Fenton treatment of sanitary LL (initial COD $=2.9-4.9 \mathrm{~g} \mathrm{O}_{2} \mathrm{~L}^{-1}$ ). Treatment cost figures of $11.0 \mathrm{EUR} \mathrm{m}^{-3}, 11.7 \mathrm{EUR} \mathrm{m}^{-3}$, and $10.9 \mathrm{EUR} \mathrm{m}^{-3}$ were estimated for the respective use of a CPC (solar photo-Fenton), UV lamps (photo-Fenton), and a combination of both, to achieve a residual COD of $0.15 \mathrm{mg} \mathrm{O}_{2} \mathrm{~L}^{-1}$. Rocha et al. (2011) [31] reported an $86 \%$ mineralization with the direct application of solar radiation to assist the photo-Fenton treatment of LL.

Overall treatment cost efficiency may be significantly improved by the application of convenient treatment combinations, such as the herein trialed coagulation pretreatment combination with a UVA-LED photo-Fenton treatment for LL. Previous research has shown how the application of pretreatment enhances the removal of ultraviolet quenching substances [3], which directly affects the efficiency of subsequent treatment steps, such as the photo-Fenton process. In a previous study, Tejera et al. reported $90 \%$ COD removal in the treatment of a reverse osmosis concentrate of LL by coagulation/flocculation followed by photo-Fenton and a final step of lime precipitation [32]. Depending on the initial characteristics of the targeted LL and the final COD objective, different potential alternatives of treatment may not be economically viable because of the high cost in chemicals, a too large surface area in the case of CPCs, and the low UV energy efficiency of high-pressure mercury-vapor immersion lamps and the inherent concern that is associated with the end-use disposal of these lamps.

Therefore, the main objective of this piece of research was to assess the alternative use of UVA-LED (ultraviolet A light emitting diode) sources of radiation as an alternative to conventional mercury-vapor immersion lamps to reduce the cost of the photo-Fenton treatment of previously coagulated mature landfill leachate. The coagulation pre-treatment removes organic matter content in an economical way and, thus, it contributes to the reduction of the overall treatment cost. In addition, it would also serve to provide the required amount of iron to perform a more cost-efficient photo-Fenton process.

\section{Material and Methods}

\subsection{Mature Landfill Leachate Characteristics}

Mature LL was collected from a landfill located in Golmayo, Soria (Spain), which was opened in 1997 and is still fully operational. This landfill contains conventional trash from nearby urban populations. This trash is currently mainly organic because, during the last few years, other types of waste, such as plastic, paper, and glass, have been separated out and recycled before dumping trash to the landfill. LL is accumulated in two ponds. One pond receives fresh $\mathrm{LL}$, which is mainly generated from recent organic trash; whereas the other pond receives mature LL, which mainly comes from older phases of exploitation when separation of trash and recycling was not yet implemented. Mature LL was sampled for this research, and its main characteristics are shown in Table 1.

\subsection{Chemicals}

Ferric chloride $\left(\mathrm{FeCl}_{3} \cdot 6 \mathrm{H}_{2} \mathrm{O}\right)$ from Sigma Aldrich (Highland, CA, USA) was used in a $69 \%(w / w)$ water solution as the coagulant. An anionic flocculant of high molecular weight, namely A-120 HMW, was purchased from Kemira (Helsinki, Finland), and was used in a $0.025 \%(w / w)$ water solution. In addition, $96-98 \%$ sulfuric acid $\left(\mathrm{H}_{2} \mathrm{SO}_{4}\right)$ was supplied by Sigma-Aldrich (Highland, CA, USA) and used for $\mathrm{pH}$ adjustment without further purification. Hydrogen peroxide (35\% $w \%$ ) from Sigma-Aldrich (Highland, CA, USA) was used as the oxidant in the photo-Fenton reaction. 
Table 1. Characteristics of the landfill leachate collected in Golmayo (Soria, Spain).

\begin{tabular}{|c|c|c|c|}
\hline Parameter & Value & Parameter & Value \\
\hline $\mathrm{pH}$ & $8.2 \pm 0.1$ & Chloride, $\mathrm{mg} \mathrm{L}^{-1}$ & $3000 \pm 137$ \\
\hline Conductivity, $\mathrm{mS} \mathrm{cm}^{-1}$ & $17.3 \pm 0.1$ & Sulfate, $\mathrm{mg} \mathrm{L}^{-1}$ & $125 \pm 23$ \\
\hline $\mathrm{UV}-254, \mathrm{~cm}^{-1}$ & $27.5 \pm 0.1$ & Aluminum, $\mathrm{mg} \mathrm{L}^{-1}$ & $5.50 \pm 0.03$ \\
\hline Color, $\mathrm{mg} \mathrm{Pt} \mathrm{L}^{-1}$ & $17,300 \pm 200$ & Iron, $\mathrm{mg} \mathrm{L}^{-1}$ & $8.50 \pm 0.01$ \\
\hline $\mathrm{COD}, \mathrm{mg} \mathrm{O}_{2} \mathrm{~L}^{-1}$ & $4961 \pm 495$ & Chromium, $\mathrm{mg} \mathrm{L}^{-1}$ & $1.9 \pm 0.05$ \\
\hline $\mathrm{BOD}_{5}, \mathrm{mg} \mathrm{O}_{2} \mathrm{~L}^{-1}$ & $149 \pm 26$ & Sodium, $\mathrm{mg} \mathrm{L}^{-1}$ & $2152 \pm 215$ \\
\hline $\mathrm{BOD}_{5} / \mathrm{COD}$ & $0.03 \pm 0.01$ & Potassium, $\mathrm{mg} \mathrm{L}^{-1}$ & $1219 \pm 122$ \\
\hline TOC, $\mathrm{mg} \mathrm{C} \mathrm{L}^{-1}$ & $1980 \pm 10$ & Magnesium, $\mathrm{mg} \mathrm{L}^{-1}$ & $98 \pm 6$ \\
\hline $\mathrm{TS}, \mathrm{mg} \mathrm{L}^{-1}$ & $21,290 \pm 1030$ & Calcium, $\mathrm{mg} \mathrm{L}^{-1}$ & $134 \pm 4$ \\
\hline $\mathrm{TSS}, \mathrm{mg} \mathrm{L}^{-1}$ & $1370 \pm 20$ & Silicon, $\mathrm{mg} \mathrm{L}^{-1}$ & $15 \pm 1$ \\
\hline TDS, $\mathrm{mg} \mathrm{L}^{-1}$ & $18,970 \pm 230$ & Zinc, $\mathrm{mg} \mathrm{L}^{-1}$ & $0.61 \pm 0.06$ \\
\hline Alkalinity, mg CaCO $3 \mathrm{~L}^{-1}$ & $13,244 \pm 100$ & Nickel, mg L ${ }^{-1}$ & $0.26 \pm 0.03$ \\
\hline $\mathrm{TN}_{\mathrm{b}}, \mathrm{mg} \mathrm{N} \mathrm{L}^{-1}$ & $1600 \pm 10$ & Copper, $\mathrm{mg} \mathrm{L}^{-1}$ & $0.03 \pm 0.01$ \\
\hline
\end{tabular}

\subsection{Coagulation}

The coagulation pre-treatment of LL was carried out by first adjusting the $\mathrm{pH}$ to 5 with $\mathrm{H}_{2} \mathrm{SO}_{4}$ and then adding $2 \mathrm{~g} \mathrm{~L}^{-1}$ ferric chloride, which is the optimum coagulation dose for the sampled LL, as has previously been reported [28]. This pre-treatment was carried out in a $5 \mathrm{~L}$ beaker filled with $3 \mathrm{~L}$ of $\mathrm{LL}$, where it was first mechanically agitated for fast mixing for $5 \mathrm{~min}$ at $150 \mathrm{rpm}$. Then, a slow agitation step at $50 \mathrm{rpm}$ was performed for $30 \mathrm{~min}$. Finally, the sample was allowed to settle without stirring for $60 \mathrm{~min}$, and the produced sludge was removed from the supernatant, which was extracted as the pre-coagulated LL to be treated next by oxidation. This procedure produced enough pre-coagulated LL to feed the reactor for its posterior photo-Fenton treatment.

\subsection{Photo-Fenton Process}

Conventional photo-assisted Fenton treatment was performed using two different high-pressure mercury-vapor immersion lamps from ACE-Glass (Vineland, NJ, USA): one of $450 \mathrm{~W}$ (Model 7825-35) and a second one of $100 \mathrm{~W}$ (Model 7825-30). The corresponding lamp was located in a quartz glass cooling jacket vertically positioned in the center of the open treatment reactor [28]. A total photon flux of $1.1 \times 10^{20}$ photon $\mathrm{m}^{-2} \mathrm{~s}^{-1}$ was produced in the reactor for the $450 \mathrm{~W}$ lamp, whereas the $100 \mathrm{~W}$ lamp resulted in $6.6 \times 10^{18}$ photon $\mathrm{m}^{-2} \mathrm{~s}^{-1}$ [33]. A total of $1.75 \mathrm{~L}$ of coagulated leachate was treated in the reactor while being mechanically stirred.

Alternatively, a UVA-LED photo-Fenton treatment was designed and performed using an $8 \mathrm{~W}$ UVA-LED lamp made up of $10 \times 365 \mathrm{~nm}$ individual LED lights (CUN6GB1A, Seoul Viosys, Asan, North Korea) evenly arranged in series over the surface of a $9 \mathrm{~cm}$ diameter open reactor. Considering this setup, a current intensity of $250 \mathrm{~mA}$ was provided to the lamp, and a total photon flux of $1.0 \times 10^{21}$ photon $\mathrm{m}^{-2} \mathrm{~s}^{-1}$ was emitted to the sample, as measured by the potassium ferrioxalate actinometry method [34,35]. The LED photoFenton reactor was filled with $100 \mathrm{~mL}$ of pre-coagulated leachate that was magnetically stirred during treatment.

The iron amount required to optimally catalyze all the performed photo-Fenton trials was provided by the remaining content after the previous coagulation treatment (300 $\mathrm{mg} \mathrm{L}^{-1}$; Table 2). The necessary amount of $\mathrm{H}_{2} \mathrm{O}_{2}$ (35\% w:w) corresponding to $\left[\mathrm{H}_{2} \mathrm{O}_{2}\right]_{0} / \mathrm{COD}_{0}$ ratio (in mg L ${ }^{-1}$ ) values of 2.125 (the stoichiometric optimum [36]), 1.063, and 0.531 was added in batch mode to actually perform the photo-Fenton treatment.

Samples were withdrawn at selected time intervals to assess the performance of the treatment. All trials were performed in triplicate, at room temperature, in open systems, and without adjusting the $\mathrm{pH}$. A schematic representation of the total process is shown in Figure 1. 
Table 2. Characteristics of the coagulated landfill leachate.

\begin{tabular}{|c|c|c|}
\hline Parameter & Raw Leachate & Coagulated Leachate* \\
\hline $\mathrm{pH}$ & $8.2 \pm 0.1$ & $2.8 \pm 0.1$ \\
\hline Conductivity, $\mathrm{mS} \mathrm{cm}-1$ & $17.3 \pm 0.1$ & $22.3 \pm 0.1$ \\
\hline $\mathrm{COD}, \mathrm{mg} \mathrm{O}_{2} \mathrm{~L}^{-1}$ & $4961 \pm 495$ & $1538 \pm 150(69 \%)$ \\
\hline $\mathrm{BOD}_{5}, \mathrm{mg} \mathrm{O}_{2} \mathrm{~L}^{-1}$ & $149 \pm 26$ & $46 \pm 15(69 \%)$ \\
\hline $\mathrm{BOD}_{5} / \mathrm{COD}$ & $0.03 \pm 0.01$ & $0.03 \pm 0.01$ \\
\hline $\mathrm{TOC}, \mathrm{mg} \mathrm{C} \mathrm{L}^{-1}$ & $1980 \pm 10$ & $614 \pm 6(69 \%)$ \\
\hline Dissolved iron, $\mathrm{mg} \mathrm{L}^{-1}$ & $8.50 \pm 0.01$ & $300 \pm 20$ \\
\hline $\mathrm{UV}-254, \mathrm{~cm}^{-1}$ & $27.5 \pm 0.1$ & $3.85 \pm 0.05(86 \%)$ \\
\hline Color, $\mathrm{mg} \mathrm{Pt} \mathrm{L}^{-1}$ & $17,300 \pm 200$ & $1750 \pm 100(90 \%)$ \\
\hline $\mathrm{TN}_{\mathrm{b}}, \mathrm{mg} \mathrm{N} \mathrm{L}^{-1}$ & $1600 \pm 10$ & $1600 \pm 10$ \\
\hline
\end{tabular}

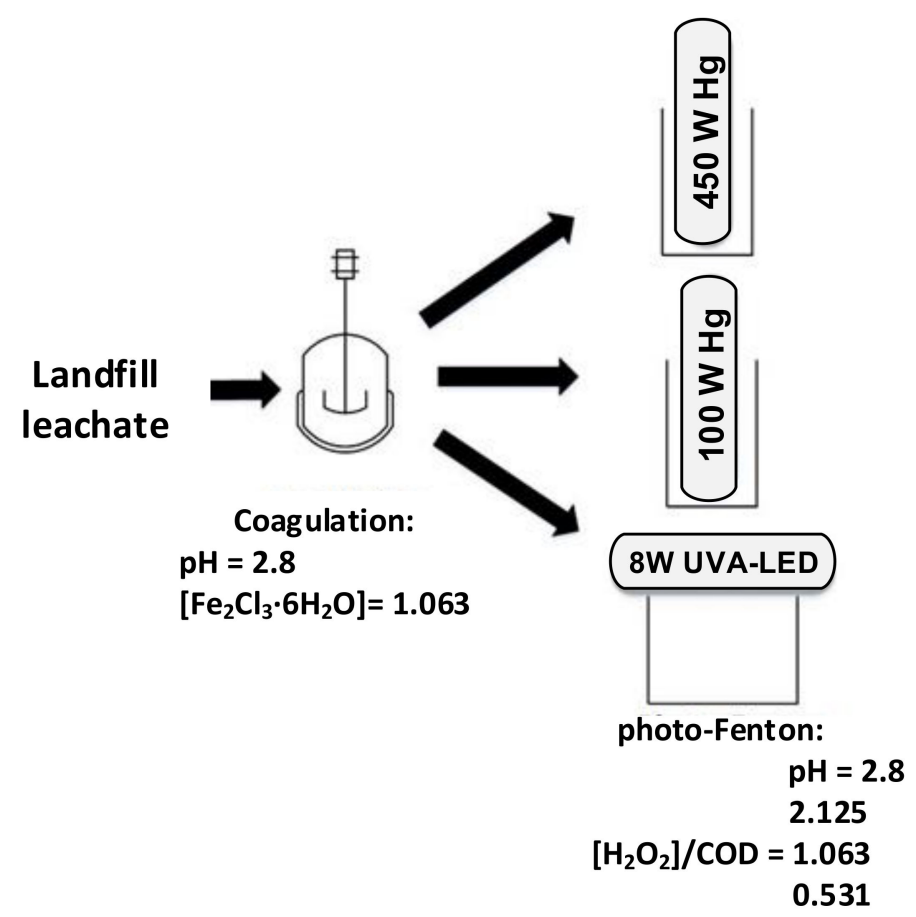

Figure 1. Schematic representation of the trialed alternative treatment strategy.

\subsection{Analytical Determinations}

All analyses were carried out according to the Standard Methods for the Examination of Water and Wastewater [37]. Conductivity and $\mathrm{pH}$ measurements were performed using a pH-meter (SensionTM + MM374 from Hach, Loveland, CO, USA) equipped with $\mathrm{pH}$ and conductivity probes. $\mathrm{BOD}_{5}$ and total alkalinity analyses were also carried out according to the respective 5210B and 2320B Standard Methods. COD, sulfate, and chloride contents were measured using Nanocolor ${ }^{\circledR}$ test methods (Macherey-Nagel GmbH, Düren, Germany) using an Aquamate UV-Vis spectrophotometer (Thermo Fisher Scientific, Waltham, MA, USA). Turbidity was determined by a Hanna LP 2000-11 turbidity meter (Hanna Instruments, Laval, QC, Canada). UV-254 absorbance was measured with a Varyan Cary 50 UV-Visible Spectrophotometer (Varian, CA, USA) using $1 \mathrm{~cm}$ pathway quartz cuvettes (Hellma, Müllheim, Germany). Total organic carbon (TOC) and the total nitrogen bound ( $\mathrm{TN}_{\mathrm{b}}$; UNE-EN-ISO 11905-1:1998) were measured by the combustion-infrared method using a TOC/TN Analyzer Multi N/C ${ }^{\circledR} 3100$ (Analytik Jena AG, Jena, Germany) with catalytic oxidation on cerium oxide at $850{ }^{\circ} \mathrm{C} . \mathrm{H}_{2} \mathrm{O}_{2}$ concentration was determined by the titanium sulfate spectrophotometric method [38]. Dissolved iron, aluminum, and calcium were measured by atomic absorption spectrometry with a Varian SpectrAA 220 spectrophotometer (Varian, CA, USA). 


\section{Results and Discussion}

\subsection{Coagulation Pre-Treatment}

This pre-treatment provided several advantages for the photo-Fenton treatment of the coagulated LL. First, it produced a $69 \%$ reduction of COD down to a value of $1538 \mathrm{mg} \mathrm{O}_{2} \mathrm{~L}^{-1}$ (Table 2). Second, it acidified the medium from the initial LL value of $\mathrm{pH}$ 8.2 down to a final $\mathrm{pH}$ of 2.8 in the coagulated LL, which is the optimum $\mathrm{pH}$ value to perform the Fenton reaction [39]. Third, up to $90 \%$ of the color was removed, which significantly favors the penetration of UV radiation into the leachate to effect treatment (Table 2). Fourth, UV-254 was reduced by $86 \%$; thus, the absorption of photons to reduce $\mathrm{Fe}^{3+}$ to $\mathrm{Fe}^{2+}$ was enhanced as well. In short, an easier photon absorption reduces irradiation time and its associated treatment cost. Finally, biodegradability was not improved, as estimated from the $\mathrm{BOD}_{5} / \mathrm{COD}$ ratio, and remained constant after coagulation, as was expected [22]. The concentration of nitrogen $\left(\mathrm{TN}_{\mathrm{b}}\right)$ was not reduced by the coagulation treatment.

These results are in accordance with our previously reported LL coagulation pretreatment assay [28], where $68 \%$ of COD were removed at the same conditions tested from an initial COD of $4961 \mathrm{mg} \mathrm{O}_{2} \mathrm{~L}^{-1}$. Amor et al. (2015) [22] produced a 63\% COD removal after the coagulation treatment of a mature LL using $2 \mathrm{~g} \mathrm{~L}^{-1}$ of $\mathrm{FeCl}_{3} \cdot 6 \mathrm{H}_{2} \mathrm{O}$ at $\mathrm{pH}$. In other previous research work, Tejera et al. (2020) [32] achieved a 76\% COD removal from an initial COD value of $21,220 \mathrm{mg} \mathrm{O}_{2} \mathrm{~L}^{-1}$ by the treatment of a reverse osmosis concentrate of LL after it was previously coagulated with $5 \mathrm{~g} \mathrm{~L}^{-1}$ of ferric chloride at $\mathrm{pH} 6$. Differences among these assays might be explained in terms of the different characteristics of each particular LL that was treated in each piece of research, the most important difference being the huge variability of initial COD between the LLs.

\subsection{Photo-Fenton Oxidation: Comparative Application of Different UV Sources}

The coagulation pre-treatment enabled the performance of a homogeneous photoFenton process of the coagulated LL without the need to add more iron than what remained after the coagulation step to adequately catalyze the photo-oxidation process.

In particular, all sources of UV radiation achieved further reductions of the COD of about the $25 \%$ for the lower added $\left[\mathrm{H}_{2} \mathrm{O}_{2}\right]_{0} / \mathrm{COD}_{0}$ ratio of 0.531 (Figure $2 \mathrm{a}-\mathrm{c}$ ), which is the expected theoretical stoichiometric value for this ratio [36]. On the other hand, certain differences in treatment efficiency were found with the different sources of irradiation at the two higher values of $\left[\mathrm{H}_{2} \mathrm{O}_{2}\right]_{0} / \mathrm{COD}_{0}$ ratios that were applied in the trials. In particular, $47 \%$ and 50\% COD removal values from the pre-coagulated LL were, respectively, achieved with the $450 \mathrm{~W}$ high-pressure $\mathrm{Hg}$ and $8 \mathrm{~W}$ LED lamps at the $\left[\mathrm{H}_{2} \mathrm{O}_{2}\right]_{0} / \mathrm{COD}_{0}$ ratio of 1.063, whereas the $100 \mathrm{~W}$ lamp was only able to reach a $41 \%$ reduction of the COD (Figure $2 \mathrm{a}-\mathrm{c}$ ). These differences may be explained by the different irradiation times of application that are required to produce such results with each irradiation source: 15 min for the $450 \mathrm{~W}$ lamp, $30 \mathrm{~min}$ for the $8 \mathrm{~W}$ UVA-LED lamp, and $150 \mathrm{~min}$ for the $100 \mathrm{~W}$ lamp.

In fact, more secondary oxidant-scavenging reactions may take place when the Fenton reaction is slower, which often occurs when the concentration of $\mathrm{H}_{2} \mathrm{O}_{2}$ and the $\left[\mathrm{H}_{2} \mathrm{O}_{2}\right] /[\mathrm{Fe}]$ ratio are higher in the solution, that is, at the highest used $\left[\mathrm{H}_{2} \mathrm{O}_{2}\right]_{0} / \mathrm{COD}_{0}$ ratio of 2.125 . As expected, greater differences in COD removal efficiencies were found among the applied UV sources, that is, $70 \%, 62 \%$, and $50 \%$ COD removal values from the coagulated LL were obtained by the $450 \mathrm{~W}, 8 \mathrm{~W}$ UVA-LED, and $100 \mathrm{~W}$ lamps, respectively, when the applied $\left[\mathrm{H}_{2} \mathrm{O}_{2}\right]_{0} / \mathrm{COD}_{0}$ ratio was the stoichiometric optimum of 2.125 (see Figure 2). The differences in the irradiation times that were correspondingly necessary to consume all the added $\mathrm{H}_{2} \mathrm{O}_{2}$ for each lamp setup were also bigger than those for $\left[\mathrm{H}_{2} \mathrm{O}_{2}\right]_{0} / \mathrm{COD}_{0}=1.063$, that is, $30 \mathrm{~min}$ for the $450 \mathrm{~W}$ lamp, $45 \mathrm{~min}$ for the UVA-LED lamp, and $180 \mathrm{~min}$ for the $100 \mathrm{~W}$ lamp. 

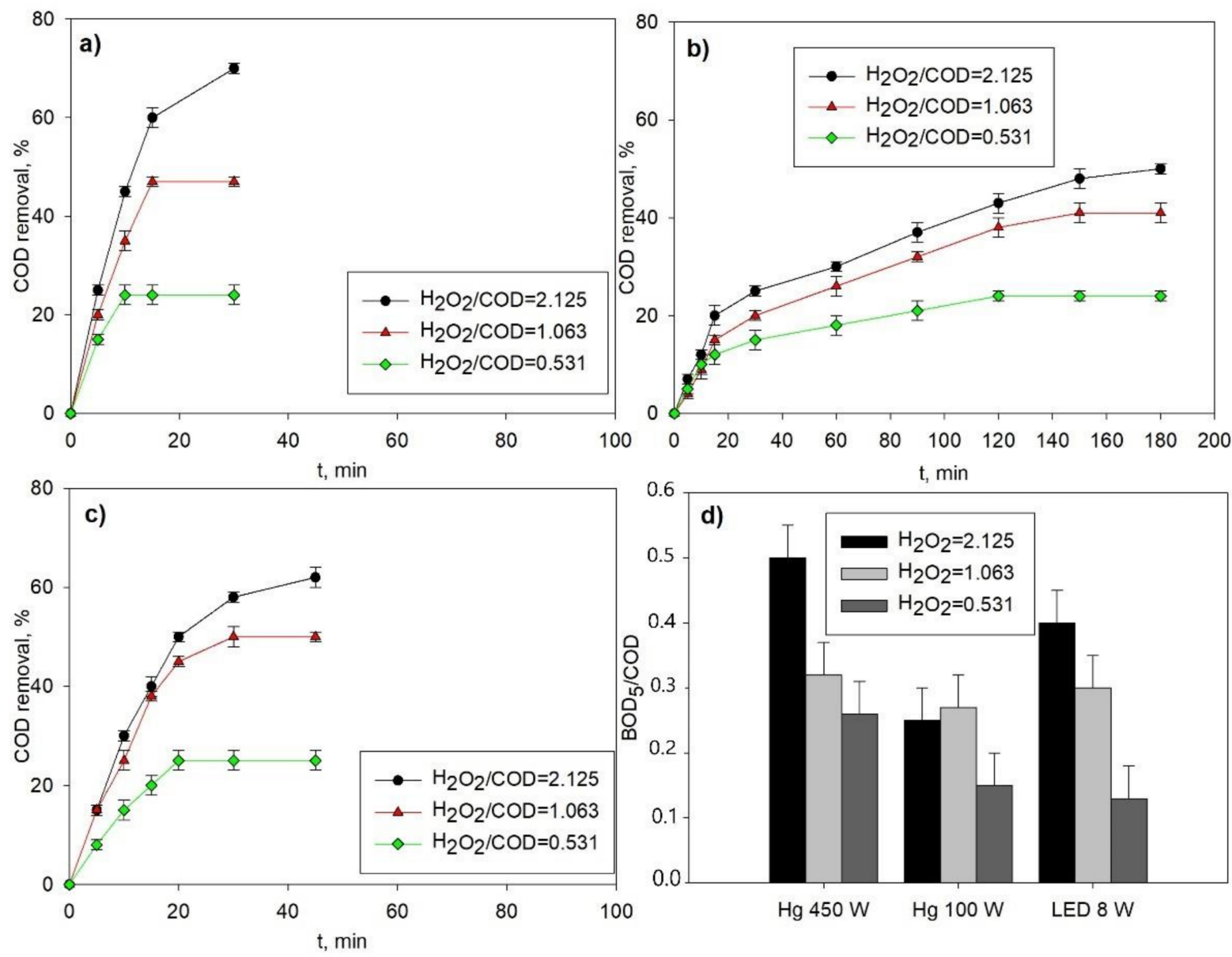

Figure 2. COD removal evolution with (a) the $450 \mathrm{~W}$ conventional photo-Fenton treatment; (b) the $100 \mathrm{~W}$ conventional photoFenton treatment; (c) the $8 \mathrm{~W}$ UVA-LED photo-Fenton alternative treatment of landfill leachate at different $\left[\mathrm{H}_{2} \mathrm{O}_{2}\right] / \mathrm{COD}$ ratios; and (d) $\mathrm{BOD}_{5} / \mathrm{COD}$ results after photo-Fenton oxidation treatments of pre-coagulated landfill leachate.

Assessing the improvement of biodegradability after a photocatalytic process, estimated as the increase of the $\mathrm{BOD}_{5} / \mathrm{COD}$ ratio in the solution, is of key importance when considering a potential subsequent tertiary biological treatment. In this sense, the biodegradability of the coagulated LL was enhanced by all the tested photo-Fenton treatment setups from its initial $\mathrm{BOD}_{5} / \mathrm{COD}$ value of 0.03 . As it was expected [25], in general, the addition of a higher $\mathrm{H}_{2} \mathrm{O}_{2}$ dosage led to an associated faster and more intense oxidation reaction (Figure 2a-c), particularly when the conventional $450 \mathrm{~W}$ lamp and the $8 \mathrm{~W}$ LED lamp were used, which further resulted in a greater COD removal and biodegradability enhancement (Figure 2). In particular, $\mathrm{BOD}_{5} / \mathrm{COD}$ increased up to 0.26 for the $450 \mathrm{~W}$ lamp, 0.15 for the $100 \mathrm{~W}$ one, and 0.13 for the LED setup when the lower amount of hydrogen peroxide $\left(\left[\mathrm{H}_{2} \mathrm{O}_{2}\right]_{0} / \mathrm{COD}_{0}=0.531\right)$ was used, whereas the $\mathrm{BOD}_{5} / \mathrm{COD}$ increased to $\approx 0.30$ for all the lamps when the $\left[\mathrm{H}_{2} \mathrm{O}_{2}\right]_{0} / \mathrm{COD}_{0}$ ratio was 1.063 . The best results of biodegradability enhancement where expectedly addressed at the stoichiometric $\left[\mathrm{H}_{2} \mathrm{O}_{2}\right]_{0} / \mathrm{COD}_{0}=2.125$ value, resulting in $\mathrm{BOD}_{5} / \mathrm{COD}$ values of 0.41 and 0.50 for the UVA-LED and 450W lamps, respectively (Table 3 ). The reaction progressed less powerfully and about four times more slowly with the conventional $100 \mathrm{~W}$ lamp (Figure 2). Therefore, more side reactions consuming $\mathrm{H}_{2} \mathrm{O}_{2}$ might take place, reducing the power of this setup to produce hydroxyl radicals from the highest supplied dose of hydrogen peroxide. As a result, increasing the dosage of $\mathrm{H}_{2} \mathrm{O}_{2}$ from $\left[\mathrm{H}_{2} \mathrm{O}_{2}\right]_{0} / \mathrm{COD}_{0}=1.063$ to 2.125 did not result in much of an increase in the removal of the COD $(+2 \%$, Table 3$)$, and biodegradability was not further enhanced at all $\left(\mathrm{BOD}_{5} / \mathrm{COD}=0.27\right.$ and 0.25 , respectively; Table 3$)$. 
The main characteristics of the resulting outflow from the photo-Fenton treatment alternatives that have been assessed are shown in Table 3. A total of $85-90 \%$ of the COD and $75-85 \%$ of the TOC were removed from the initial LL value (Tables 1 and 3), respectively, under the best assessed treatment conditions (optimal $\mathrm{FeCl}_{3}$ coagulation followed by a photo-Fenton treatment performed at $\left[\mathrm{H}_{2} \mathrm{O}_{2}\right] / \mathrm{COD}=1.063-2.125$ either using a $450 \mathrm{~W}$ mercury-vapor immersion lamp or an $8 \mathrm{~W} 365 \mathrm{~nm}$ LED lamp). The conventional $100 \mathrm{~W}$ lamp produced lower removal results in general. In all the cases, color was very highly removed (>97\%) as was UV-254 (92-97\%), COD, and TOC. On the other hand, nitrogen content was not significantly removed (Table 3); thus, the treatment strategy of this mature LL may require other steps, such as a step to strip out nitrogen.

Table 3. Characteristics of landfill leachate after photo-Fenton treatment with 450 and $100 \mathrm{~W}$ mercury-vapor immersion lamps and an $8 \mathrm{~W}$ UVA-LED lamp at $\mathrm{H}_{2} \mathrm{O}_{2} / \mathrm{COD}=2.125,1.063$, and 0.531 ratios.

\begin{tabular}{|c|c|c|c|c|c|c|c|c|c|}
\hline \multirow{2}{*}{ 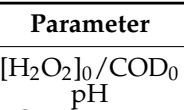 } & \multicolumn{3}{|c|}{$\mathrm{Hg} 450 \mathrm{~W}$} & \multicolumn{3}{|c|}{$\mathrm{Hg} 100 \mathrm{~W}$} & \multicolumn{3}{|c|}{ LED $8 \mathrm{~W}$} \\
\hline & $\begin{array}{c}0.531 \\
3.2 \pm 0.1\end{array}$ & $\begin{array}{c}1.063 \\
3.6 \pm 0.1\end{array}$ & $\begin{array}{c}2.125 \\
4.0 \pm 0.1\end{array}$ & $\begin{array}{c}0.531 \\
3.0 \pm 0.1\end{array}$ & $\begin{array}{c}1.063 \\
3.3 \pm 0.1\end{array}$ & $\begin{array}{c}2.125 \\
3.8 \pm 0.1\end{array}$ & $\begin{array}{c}0.531 \\
3.3 \pm 0.1\end{array}$ & $\begin{array}{c}1.063 \\
3.6 \pm 0.1\end{array}$ & $\begin{array}{c}2.125 \\
3.8 \pm 0.1\end{array}$ \\
\hline $\begin{array}{l}\text { Conductivity } \\
\mathrm{mS} \mathrm{cm}^{-1}\end{array}$ & $22.5 \pm 0.1$ & $22.8 \pm 0.1$ & $23.4 \pm 0.1$ & $22.4 \pm 0.1$ & $22.5 \pm 0.1$ & $22.9 \pm 0.1$ & $22.2 \pm 0.1$ & $22.6 \pm 0.1$ & $23.0 \pm 0.1$ \\
\hline $\mathrm{mg} \mathrm{O}_{2} \mathrm{~L}^{-1}$ & $\begin{array}{c}1169 \pm 100 \\
(76 \%)\end{array}$ & $\begin{array}{c}815 \pm 80 \\
(84 \%)\end{array}$ & $\begin{array}{l}461 \pm 40 \\
\quad(91 \%)\end{array}$ & $\begin{array}{c}1169 \pm 150 \\
(76 \%)\end{array}$ & $\begin{array}{c}907 \pm 90 \\
(82 \%)\end{array}$ & $\begin{array}{c}769 \pm 80 \\
(84 \%)\end{array}$ & $\begin{array}{c}1153 \pm 110 \\
(77 \%)\end{array}$ & $\begin{array}{c}769 \pm 70 \\
(84 \%)\end{array}$ & $\begin{array}{c}564 \pm 50 \\
(89 \%)\end{array}$ \\
\hline $\begin{array}{c}\mathrm{BOD}_{5} \\
\mathrm{mg} \mathrm{O}_{2} \mathrm{~L}^{-1}\end{array}$ & $304 \pm 30$ & $261 \pm 30$ & $230 \pm 20$ & $175 \pm 20$ & $245 \pm 20$ & $192 \pm 20$ & $150 \pm 30$ & $231 \pm 20$ & $234 \pm 20$ \\
\hline $\begin{array}{c}\mathrm{BOD}_{5} / \mathrm{COD} \\
\mathrm{TOC}^{-1} \\
\mathrm{mg} \mathrm{C} \mathrm{L}^{-1}\end{array}$ & $\begin{array}{c}0.26 \pm 0.05 \\
556 \pm 40 \\
(72 \%)\end{array}$ & $\begin{array}{c}0.32 \pm 0.05 \\
495 \pm 50 \\
(75 \%)\end{array}$ & $\begin{array}{c}0.50 \pm 0.05 \\
297 \pm 30 \\
(85 \%)\end{array}$ & $\begin{array}{c}0.15 \pm 0.05 \\
594 \pm 60 \\
(70 \%)\end{array}$ & $\begin{array}{c}0.27 \pm 0.05 \\
554 \pm 50 \\
(72 \%)\end{array}$ & $\begin{array}{c}0.25 \pm 0.05 \\
495 \pm 50 \\
(75 \%)\end{array}$ & $\begin{array}{c}0.13 \pm 0.05 \\
535 \pm 50 \\
(73 \%)\end{array}$ & $\begin{array}{c}0.30 \pm 0.05 \\
436 \pm 40 \\
(78 \%)\end{array}$ & $\begin{array}{c}0.41 \pm 0.05 \\
356 \pm 30 \\
(82 \%)\end{array}$ \\
\hline $\begin{array}{l}\text { Dissolved Fe } \\
\mathrm{mg} \mathrm{L}^{-1}\end{array}$ & $290 \pm 20$ & $285 \pm 30$ & $270 \pm 20$ & $295 \pm 30$ & $280 \pm 30$ & $275 \pm 20$ & $285 \pm 20$ & $280 \pm 30$ & $275 \pm 20$ \\
\hline $\begin{array}{c}\text { UV-254 } \\
\mathrm{cm}^{-1}\end{array}$ & $\begin{array}{c}2.31 \pm 0.05 \\
(92 \%)\end{array}$ & $\begin{array}{c}1.54 \pm 0.05 \\
(94 \%)\end{array}$ & $\begin{array}{c}0.77 \pm 0.05 \\
(97 \%)\end{array}$ & $\begin{array}{c}2.28 \pm 0.05 \\
(92 \%)\end{array}$ & $\begin{array}{c}1.70 \pm 0.05 \\
(94 \%)\end{array}$ & $\begin{array}{c}1.0 \pm 0.05 \\
(96 \%)\end{array}$ & $\begin{array}{c}2.20 \pm 0.05 \\
(92 \%)\end{array}$ & $\begin{array}{c}1.35 \pm 0.05 \\
(95 \%)\end{array}$ & $\begin{array}{c}0.85 \pm 0.05 \\
(97 \%)\end{array}$ \\
\hline $\begin{array}{c}\text { Color } \\
\mathrm{mg} \mathrm{Pt} \mathrm{L}^{-1}\end{array}$ & $\begin{array}{c}450 \pm 20 \\
(97 \%)\end{array}$ & $\begin{array}{c}360 \pm 20 \\
(98 \%)\end{array}$ & $\begin{array}{c}200 \pm 30 \\
(99 \%)\end{array}$ & $\begin{array}{c}500 \pm 40 \\
(97 \%)\end{array}$ & $\begin{array}{c}380 \pm 20 \\
(98 \%)\end{array}$ & $\begin{array}{c}230 \pm 40 \\
(99 \%)\end{array}$ & $\begin{array}{c}400 \pm 20 \\
(98 \%)\end{array}$ & $\begin{array}{c}340 \pm 30 \\
(98 \%)\end{array}$ & $\begin{array}{c}210 \pm 20 \\
(99 \%)\end{array}$ \\
\hline $\begin{array}{c}\mathrm{TN}_{\mathrm{b}} \\
\operatorname{mg~N~L}^{-1}\end{array}$ & $1600 \pm 100$ & $1600 \pm 100$ & $1600 \pm 100$ & $1600 \pm 100$ & $1600 \pm 100$ & $1600 \pm 100$ & $1600 \pm 100$ & $1600 \pm 100$ & $1600 \pm 100$ \\
\hline
\end{tabular}

Total removal percentages from initial LL values are included in brackets.

\subsection{Energy Consumption and Its Preliminary Economic Assessment}

The main difference among the used photo-Fenton treatment setups was the power consumption of each lamp, which, considering the time of irradiation that was necessary to achieve the final treatment results, provides the energy use of each treatment configuration. Therefore, it is the primary factor affecting the cost of the treatment (Table 4) as it

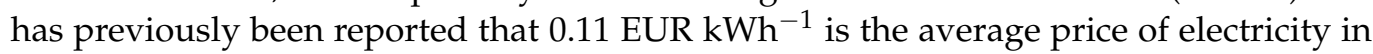
Spain [28,32].

The longest irradiation time (2-3 h) required by the $100 \mathrm{~W}$ high-pressure mercuryvapor immersion lamp to complete the reaction resulted in very high treatment costs $\left(>12\right.$ EUR m $^{-3}$ ), corresponding to $>114 \mathrm{kWh}$; thus, the implementation of this technology would be very disadvantageous at an industrial scale.

On the other hand, the $450 \mathrm{~W}$ high-pressure mercury-vapor immersion lamp required less than $30 \mathrm{~min}$ of irradiation to complete the treatment with its best performance $\left(\left[\mathrm{H}_{2} \mathrm{O}_{2}\right]_{0} / \mathrm{COD}_{0}=2.125\right)$, reducing the cost of treatment in comparison to the $100 \mathrm{~W}$ lamp by about $25 \%$ and providing $20 \%$ more COD removal (Table 4 ).

The treatment time required to finish the oxidation reaction when the $8 \mathrm{~W}$ UVA-LED lamp was used was not much higher (10-15 min more) than in the case of the $450 \mathrm{~W}$ lamp, but the power efficiency was much higher for this lamp $(8 \mathrm{~W})$ than for the other lamps (about half the $\mathrm{kW} \mathrm{h} \mathrm{m}^{-3}$ of energy were used; Table 4 ). Therefore, the cost of treatment was reduced to $35-55 \%\left(2.93-6.60\right.$ EUR m$\left.^{-3}\right)$ with respect to the use of the $450 \mathrm{~W}$ lamp (4.62-14.20 EUR $\mathrm{m}^{-3}$ ). In addition, the UVA-LED lamp has the advantage of containing no mercury, which requires special disposal.

The novel immersion lamps were 50\% more efficient in emitting UV radiation in relation to the consumed power than were the previously used lamps, as has been addressed [28], and the LED technology could also produce impressive figures in terms of 
treatment efficiency and operational costs provided there is room to improve the efficiency of the applied UVA-LED lamp prototype.

Table 4. Energy cost of the assessed alternative photo-Fenton processes using different radiation sources.

\begin{tabular}{|c|c|c|c|c|c|c|c|}
\hline UV Source & {$\left[\mathrm{H}_{2} \mathrm{O}_{2}\right]_{0} / \mathrm{COD}_{0}$} & $\begin{array}{c}\text { COD } \\
\text { Removal \% }\end{array}$ & $\mathrm{BOD}_{5} / \mathrm{COD}$ & $\begin{array}{c}t \\
\min \end{array}$ & $\begin{array}{c}E \\
\mathrm{kWh} \mathrm{m}^{-3}\end{array}$ & $\begin{array}{c}\text { Cost } \\
\text { EUR } \mathrm{m}^{-3}\end{array}$ & $\begin{array}{c}\text { Cost } \\
\text { EUR } \mathrm{kg} \mathrm{COD}^{-1}\end{array}$ \\
\hline \multirow{3}{*}{$\mathrm{Hg}(450 \mathrm{~W})$} & 0.531 & $24 \pm 2$ & $0.26 \pm 0.05$ & 10 & 42 & 4.62 & 12.5 \\
\hline & 1.063 & $47 \pm 3$ & $0.32 \pm 0.05$ & 15 & 64 & 7.04 & 9.7 \\
\hline & 2.125 & $70 \pm 4$ & $0.50 \pm 0.05$ & 30 & 129 & 14.20 & 13.2 \\
\hline \multirow{3}{*}{$\mathrm{Hg}(100 \mathrm{~W})$} & 0.531 & $24 \pm 2$ & $0.15 \pm 0.05$ & 120 & 114 & 12.50 & 33.9 \\
\hline & 1.063 & $41 \pm 4$ & $0.27 \pm 0.05$ & 150 & 143 & 15.71 & 24.9 \\
\hline & 2.125 & $50 \pm 3$ & $0.25 \pm 0.05$ & 180 & 171 & 18.80 & 24.4 \\
\hline \multirow{3}{*}{ LED (8 W) } & 0.531 & $25 \pm 1$ & $0.13 \pm 0.05$ & 20 & 27 & 2.93 & 7.6 \\
\hline & 1.063 & $50 \pm 2$ & $0.30 \pm 0.05$ & 30 & 40 & 4.40 & 5.7 \\
\hline & 2.125 & $62 \pm 4$ & $0.40 \pm 0.05$ & 45 & 60 & 6.60 & 6.9 \\
\hline
\end{tabular}

t: reaction time; E: consumed energy; Hg: high-pressure mercury-vapor lamp.

These results are in accordance with other previous work [32], in which a reverse osmosis concentrate of LL was treated by coagulation followed by a photo-Fenton process either using a $100 \mathrm{~W}$ Hg vapor immersion lamp or a UVA-LED alternative lamp as its source of radiation. The UVA-LED lamp cost $16 \%$ less for power consumption during the oxidation step.

\section{Conclusions}

The proposed treatment combination based on a coagulation pre-treatment with ferric chloride followed by a photo-Fenton process was determined to be very efficient for the treatment of landfill leachate, removing up to the $90 \%$ of the COD under the best trialed treatment conditions.

The coagulation pre-treatment reduced $70 \%$ of the COD, and in addition to providing the necessary iron content to catalyze the photo-Fenton process, it also acidified the medium to a final $\mathrm{pH}$ of 2.8, which is the optimum $\mathrm{pH}$ to perform the Fenton reaction. In addition, it also clarified the solution removing up to $90 \%$ of the color, thus favoring the penetration of radiation to effect treatment.

The UVA-LED lamp and the $450 \mathrm{~W}$ lamp showed more similar photo-Fenton treatment efficiency figures $(60-70 \%$ reduction of the remaining COD in the pre-coagulated LL in the best case), whereas the $100 \mathrm{~W}$ high-pressure mercury-vapor immersion lamp was the least efficient in terms of COD removal and biodegradability enhancement.

The biodegradability of the leachate was also enhanced up to a $\mathrm{BOD}_{5} / \mathrm{COD}$ of 0.4 and 0.5 in the best cases, which were achieved by the $8 \mathrm{~W}$ UVA-LED lamp and the $450 \mathrm{~W}$ highpressure mercury-vapor immersion lamp, respectively. The faster the oxidation process was, the higher were the treatment efficiency and biodegradability enhancement values, presumably because the potential occurrence of scavenging reactions was limited.

UVA-LED technology exhibited similar competitive treatment efficiency and better energy cost figures than those of the $450 \mathrm{~W}$ high-pressure mercury-vapor immersion lamp. The $100 \mathrm{~W}$ lamp showed the worst treatment energy cost figures. Implementation and final lamp disposal costs are also expected to be lower in the case of UVA-LED technology than when high-pressure mercury-vapor lamps are used.

Author Contributions: Conceptualization, Á.B., D.H., and C.N.; methodology, D.H., A.G., J.T., and V.A.-G.; validation, J.T., D.H. and C.N.; formal analysis, J.T., D.H. and Á.B.; investigation, J.T., A.G. and V.A.-G.; resources, Á.B. and C.N.; data curation, Á.B., J.T. and D.H.; writing-original draft preparation, J.T., D.H. and Á.B.; writing-review and editing, J.T., D.H., Á.B., A.G. and C.N.; visualization, A.G. and Á.B.; supervision, Á.B. and C.N.; project administration, Á.B. and C.N.; funding acquisition, Á.B. All authors have read and agreed to the published version of the manuscript. 
Funding: The Spanish Ministry of Economy, Industry and Competitiveness granted project CTM201677948-R, and the Community of Madrid has funded project RETOPROSOST-2 (S2018/EMT-4459).

Institutional Review Board Statement: Not applicable.

Informed Consent Statement: Not applicable.

Data Availability Statement: Not applicable.

Acknowledgments: The authors acknowledge Golmayo's Center of Waste Management (Soria, Spain) for kindly supplying the LL used in this study.

Conflicts of Interest: The authors declare no conflict of interest.

\section{References}

1. Pelkonen, M.; Wang, Y. Leachate direct-discharge limits and incentives related to landfill aftercare costs. J. Mater. Cycles Waste Manag. 2017, 19, 413-422. [CrossRef]

2. Tripathy, B.K.; Kumar, M. Sequential coagulation/flocculation and microwave-persulfate processes for landfill leachate treatment: Assessment of bio-toxicity, effect of pretreatment and cost-analysis. Waste Manag. 2019, 85, 18-29. [CrossRef]

3. Iskander, S.M.; Zhao, R.; Pathak, A.; Gupta, A.; Pruden, A.; Novak, J.T.; He, Z. A review of landfill leachate induced ultraviolet quenching substances: Sources, characteristics, and treatment. Water Res. 2018, 145, 297-311. [CrossRef]

4. Wang, K.; Li, L.; Tan, F.; Wu, D. Treatment of landfill leachate using activated sludge technology: A review. Archaea 2018, 2018, 1039453. [CrossRef] [PubMed]

5. Luo, H.; Zeng, Y.; Cheng, Y.; He, D.; Pan, X. Recent advances in municipal landfill leachate: A review focusing on its characteristics, treatment, and toxicity assessment. Sci. Total Environ. 2020, 703, 135468. [CrossRef]

6. Bove, D.; Merello, S.; Frumento, D.; Al Arni, S.; Aliakbarian, B.; Converti, A. A Critical Review of Biological Processes and Technologies for Landfill Leachate Treatment. Chem. Eng. Technol. 2015, 38, 2115-2126. [CrossRef]

7. Colombo, A.; Módenes, A.N.; Trigueros, D.E.G.; da Costa, S.I.G.; Borba, F.H.; Espinoza-Quiñones, F.R. Treatment of sanitary landfill leachate by the combination of photo-Fenton and biological processes. J. Clean. Prod. 2019, 214, 145-153. [CrossRef]

8. Hilles, A.H.; Amr, S.S.A.; Hussein, R.A.; El-Sebaie, O.D.; Arafa, A.I. Performance of combined sodium persulfate/ $\mathrm{H}_{2} \mathrm{O}_{2}$ based advanced oxidation process in stabilized landfill leachate treatment. J. Environ. Manag. 2016, 166, 493-498. [CrossRef]

9. Iskander, S.M.; Novak, J.T.; Brazil, B.; He, Z. Percarbonate oxidation of landfill leachates towards removal of ultraviolet quenchers. Environ. Sci. Water Res. Technol. 2017, 3, 1162-1170. [CrossRef]

10. Jia, C.; Wang, Y.; Zhang, C.; Qin, Q. UV-TiO 2 photocatalytic degradation of landfill leachate. Water Air Soil Pollut. 2011, 217, 375-385. [CrossRef]

11. Litter, M.I.; Slodowicz, M. An overview on heterogeneous Fenton and photoFenton reactions using zerovalent iron materials. J. Adv. Oxid. Technol. 2017, 20, 19. [CrossRef]

12. Turro, E.; Giannis, A.; Cossu, R.; Gidarakos, E.; Mantzavinos, D.; Katsaounis, A. Electrochemical oxidation of stabilized landfill leachate on DSA electrodes. J. Hazard. Mater. 2011, 190, 460-465. [CrossRef]

13. Umar, M.; Aziz, H.A.; Yusoff, M.S. Trends in the use of Fenton, electro-Fenton and photo-Fenton for the treatment of landfill leachate. Waste Manag. 2010, 30, 2113-2121. [CrossRef]

14. Wu, C.; Chen, W.; Gu, Z.; Li, Q. A review of the characteristics of Fenton and ozonation systems in landfill leachate treatment. Sci. Total Environ. 2020, 143131. [CrossRef]

15. Bautista, P.; Mohedano, A.F.; Casas, J.A.; Zazo, J.A.; Rodriguez, J.J. An overview of the application of Fenton oxidation to industrial wastewaters treatment. J. Chem. Technol. Biotechnol. 2008, 83, 1323-1338. [CrossRef]

16. Deng, Y.; Englehardt, J.D. Treatment of landfill leachate by the Fenton process. Water Res. 2006, 40, 3683-3694. [CrossRef] [PubMed]

17. Zhang, M.-H.; Dong, H.; Zhao, L.; Wang, D.-X.; Meng, D. A review on Fenton process for organic wastewater treatment based on optimization perspective. Sci. Total Environ. 2019, 670, 110-121. [CrossRef]

18. Cassano, D.; Zapata, A.; Brunetti, G.; Del Moro, G.; Di Iaconi, C.; Oller, I. Comparison of several combined/integrated biologicalAOPs setups for the treatment of municipal landfill leachate: Minimization of operating costs and effluent toxicity. Chem. Eng. J. 2011, 172, 250-257. [CrossRef]

19. Durán, A.; Monteagudo, J.; San Martín, I. Photocatalytic treatment of an industrial effluent using artificial and solar UV radiation: An operational cost study on a pilot plant scale. J. Environ. Manag. 2012, 98, 1-4. [CrossRef]

20. Silva, T.F.; Ferreira, R.; Soares, P.A.; Manenti, D.R.; Fonseca, A.; Saraiva, I. Insights into solar photo-Fenton reaction parameters in the oxidation of a sanitary landfill leachate at lab-scale. J. Environ. Manag. 2015, 164, 32-40. [CrossRef] [PubMed]

21. Singa, P.K.; Isa, M.H.; Ho, Y.-C.; Lim, J.-W. Mineralization of hazardous waste landfill leachate using photo-fenton process. In E3S Web of Conferences; EDP Sciences: Evry, France, 2018.

22. Amor, C.; De Torres-Socías, E.; Peres, J.A.; Maldonado, M.I.; Oller, I.; Malato, S. Mature landfill leachate treatment by coagulation/flocculation combined with Fenton and solar photo-Fenton processes. J. Hazard. Mater. 2015, 286, 261-268. [CrossRef] 
23. Gomes, A.I.; Silva, T.F.; Duarte, M.A.; Boaventura, R.A.; Vilar, V.J. Cost-effective solar collector to promote photo-Fenton reactions: A case study on the treatment of urban mature leachate. J. Clean. Prod. 2018, 199, 369-382. [CrossRef]

24. Silva, T.F.; Fonseca, A.; Saraiva, I.; Boaventura, R.A.; Vilar, V.J. Scale-up and cost analysis of a photo-Fenton system for sanitary landfill leachate treatment. Chem. Eng. J. 2016, 283, 76-88. [CrossRef]

25. Will, I.; Moraes, J.; Teixeira, A.; Guardani, R.; Nascimento, C. Photo-Fenton degradation of wastewater containing organic compounds in solar reactors. Sep. Purif. Technol. 2004, 34, 51-57. [CrossRef]

26. Smaoui, Y.; Mseddi, S.; Ayadi, N.; Sayadi, S.; Bouzid, J. Evaluation of influence of coagulation/flocculation and Fenton oxidation with iron on landfill leachate treatment. Environ. Prot. Eng. 2019, 45. [CrossRef]

27. Zhao, J.; Ouyang, F.; Yang, Y.; Tang, W. Degradation of recalcitrant organics in nanofiltration concentrate from biologically pretreated landfill leachate by ultraviolet-Fenton method. Sep. Purif. Technol. 2020, 235, 116076. [CrossRef]

28. Tejera, J.; Miranda, R.; Hermosilla, D.; Urra, I.; Negro, C.; Blanco, Á. Treatment of a Mature Landfill Leachate: Comparison between Homogeneous and Heterogeneous Photo-Fenton with Different Pretreatments. Water 2019, 11, 1849. [CrossRef]

29. Borba, F.H.; Leichtweis, J.; Bueno, F.; Pellenz, L.; Inticher, J.J.; Seibert, D. Pollutant removal and acute toxicity assessment (Artemia salina) of landfill leachate treated by photo-Fenton process mediated by oxalic acid. J. Water Process Eng. 2019, 28, 159-168. [CrossRef]

30. Seibert, D.; Diel, T.; Welter, J.B.; de Souza, A.L.; Módenes, A.N.; Espinoza-Quiñones, F.R. Performance of photo-Fenton process mediated by Fe (III)-carboxylate complexes applied to degradation of landfill leachate. J. Environ. Chem. Eng. 2017, 5, 4462-4470. [CrossRef]

31. Rocha, E.M.; Vilar, V.J.; Fonseca, A.; Saraiva, I.; Boaventura, R.A. Landfill leachate treatment by solar-driven AOPs. Sol. Energy 2011, 85, 46-56. [CrossRef]

32. Tejera, J.; Hermosilla, D.; Miranda, R.; Gascó, A.; Alonso, V.; Negro, C.; Blanco, A. Assessing an Integral Treatment for Landfill Leachate Reverse Osmosis Concentrate. Catalysts 2020, 10, 1389. [CrossRef]

33. Liang, X.; Zhu, X.; Butler, E.C. Comparison of four advanced oxidation processes for the removal of naphthenic acids from model oil sands process water. J. Hazard. Mater. 2011, 190, 168-176. [CrossRef] [PubMed]

34. Hatchard, C.; Parker, C.A. A new sensitive chemical actinometer-II. Potassium ferrioxalate as a standard chemical actinometer. Proc. R. Soc. Lond. Ser. Math. Phys. Sci. 1956, 235, 518-536.

35. Montalti, M.; Credi, A.; Prodi, L.; Gandolfi, M.T. Handbook of Photochemistry; CRC Press: Boca Raton, FL, USA, 2006.

36. Kim, S.-M.; Geissen, S.-U.; Vogelpohl, A. Landfill leachate treatment by a photo-assisted Fenton reaction. Water Sci. Technol. 1997, 35, 239-248. [CrossRef]

37. Federation, Water Environmental; APH Association. Standard Methods for the Examination of Water and Wastewater; American Public Health Association (APHA): Washington, DC, USA, 2005.

38. Pobiner, H. Determination of hydroperoxides in hydrocarbon by conversion to hydrogen peroxide and measurement by titanium complexing. Anal. Chem. 1961, 33, 1423-1426. [CrossRef]

39. Hermosilla, D.; Cortijo, M.; Huang, C.P. Optimizing the treatment of landfill leachate by conventional Fenton and photo-Fenton processes. Sci. Total Environ. 2009, 407, 3473-3481. [CrossRef] [PubMed] 